студентів, важливих для формування їх наукового світогляду і хімікофармацевтичної культури.

\title{
Література:
}

1. Березюк О.С. Шляхи модернізації освітньої системи України / О.С. Березюк, В.І. Смоляр, О.М. Власенко. Тенденції модернізації національних освітніх систем: збірник наукових праць/за ред. О.С. Березюк. Житомир : Вид-во ЖДУ ім. І. Франка, 2014. 158 с.

DOI https://doi.org/10.30525/978-9934-588-81-5-2.26

\section{РЕЛЕВАНТНІСТЬ ЗАСТОСУВАННЯ КОМПЛЕКСНИХ ГОМЕОПАТИЧНИХ ПРЕПАРАТІВ ЯК АЛЬТЕРНАТИВНОГО МЕТОДУ ТЕРАПІЇ СИНДРОМУ ХРОНІЧНОЇ ВТОМИ}

\author{
Неляпіна М. М. \\ студентка V курсу кафедри загальної практики-сімейної медицини \\ медичного факультету \\ Харківський наиіональний університет імені В. Н. Каразіна \\ Гайдукова О. О. \\ кандидат фармачевтичних наук, \\ асистент кафедри загальної практики-сімейної медицини \\ Харківський національний університет імені В. Н. Каразіна
}

Мінаєва А. О.

кандидат біологічних наук, асистент кафедри загальної практики-сімейної медицини Харківський національний університет імені В. Н. Каразіна

\section{Салун О. О.}

асистент кафедри загальної практики-сімейної медицини Харківський національний університет імені В. Н. Каразіна

Павлова О. Л.

асистент кафедри загальної практики-сімейної медицини Харківський національний університет імені В. Н. Каразіна м. Харків, Україна

Діаметральні наукові суперечності вітчизняних та зарубіжних терапевтичних шкіл щодо диференціації синдрому хронічної втоми (CXВ) як окремої нозологічної одиниці, зумовлюють сучасні тенденції до його різнобічного дослідження. Надзвичайна поліморфність симптоматичних проявів цієї патології, її клінічна «мімікрія» інших 
хвороб психоневрологічного та соматичного спектру, а також відсутність чіткого морфологічного субстрату є головними причинами дискутабельності вчених із приводу постійного пошуку коректних лікувальних засобів, які мають авторитетну доказову базу.

Сьогодні СХВ (доброякісний міалгійний енцефаломієліт, астенодепресивний синдром, нейроміастенія) є біопсихосоціальним феноменом, симптоми якого уражають майже всі системи організму. Крім того, його вважають «медичною сиротою», адже ще й досі для нього не створені чіткі протоколи лікування. Надмірна швидкість індустріалізації економічно розвинених країн спровокувала зростання кількості зафіксованих випадків СХВ, тому що цю патологію вважають «хворобою цивілізації». Досліджуване захворювання є убіквітарним - воно не має детермінації за географічними або соціально-демографічними критеріями, проте, частіше реєструється у мегаполісах із високою щільністю населення, рівнем і темпом життя, а також низькою стреспротективною активністю. Не менш важливим фактором, що виступає індуктором виникнення $\mathrm{CXB}, \epsilon$ дисбаланс системи емоційнокогнітивного навантаження, а також дисгармонізація режиму дня, що стає тригером у формуванні «circulus vituosus».

Слід зауважити, що не дивлячись на велику кількість наукових праць, присвячених різних ланкам патогенезу СХВ, точна етіологія хвороби не встановлена та залишається перспективним напрямком для досліджень. Серед найвідоміших гіпотез - бактеріальна, вірусна, а також теорія сімейної генетичної детермінації.

У сучасній медичній практиці термін «СХУ» часто асоціюють із дефініцією «синдром офісного працівника». Їх об'єднує цілий ряд аналогічних синдромів. Існує думка, що однією із етіологічних засад обох захворювань $є$ деструкція клітинних мембран під дією надлишку іонів кальцію, який виконує антагоністичні магнію функції в організмі [6, с. 171].

Континуум вищенаведеного зумовлює мультифакторіальність та багатовекторність СХВ як виснажливої набутої патології, що в свою чергу змушує створювати нові менеджменти щодо функціональних діагностичних інтервенцій, профілактики та апробації модернових методів лікування.

Останніми роками були опубліковані дослідження щодо корекції симптоматики СXВ за допомогою комбінованої транскраніальної фізіотерапії. Показано, що використання даної методики як моно-засіб супроводжується ліквідацією ознак вегетативної дисфункції і дезадаптації більш ніж у половини пацієнтів. Однак, медицина сьогодення має тенденцію до зниження інвазійних методів як діагностики, так i 
лікування, тому консервативні засоби терапії вважаються найбільш раціональними [4, с. 20].

Також сьогодні перспективним напрямом наукових досліджень фармакологічної практики $є$ створення й застосування лікарських композитум-форм, які здатні впливати на різні етапи патологічного процесу. Ми звернули свою увагу на гомеопатичний метод лікування CXB. Чому? 3 точки зору гомеопатичної медицини такі стани як CXB, належать до захворювань міазматичної природи описуються в класичній гомеопатії [2, с. 182].

Аналізуючи дані літератури можна зробити висновок, що як правило призначаються гомеопатичні монопрепарати у різних розведеннях та комплексні ліки $[9$, с. 84]. В Росії розроблені комплексні гомеопатичні лікарські засоби (КГомЛЗ) саме для лікування СХВ. Це такі препарати: «Берталіс» («Едас-155», «Едас-995») (ЗАТ «Міжнародний концерн «Едас», Росія), «Імуніум-клінік» (ВАТ «Фітасинтекс», Росія), «Герантол» та «Гінкго-акорд» (ТОВ «Гутта», Росія). Також лікарі при лікуванні СХВ часто використовують КГомЛП фірми «Biologische Heilmittel Heel GmbH» (Нiмеччина) такі, як «Коензим композитум», «Дискус композитум», «Убіхінон композитум», «Енгістол», «Ехінацея композитум». Але вони не призначені саме для лікування даного синдрому та виступають в якості допоміжної терапії для усунення ряду симптомів захворювання та покращення загального стану хворих. На українському фармацевтичному ринку є КГомЛП «Стрес-гран» (ЗАТ «Національний гомеопатичний союз»), який нормалізує стан після стресу, втоми та виснаження та може використовується для полегшення загального стану організму в тому числі й при СХВ. Отже, український фармацевтичний ринок ГомЛЗ для лікування СХВ є дуже обмеженим.

Враховуючи віще зазначене, нами був розроблений КГомЛЗ для лікування СХВ «Тонус-актив» $[1$, с. 10]. Маючи на меті подальше його впровадження до рутинної медичної практики, була проведена апробація та доклінічні дослідження щодо вивчення його специфічної активності.

Стреспротективну дію КГомЛЗ «Тонус-актив» та засобу порівняння - гомеопатичного препарату «Стрес-гран» вивчали на моделі нервово-м'язового напруження за Сельє [5, с. 201]. Для оцінки впливу «Тонус-активу» на функціональний стан ЦНС використовували загальноприйнятий в експериментальній токсикології інтегральний тест «відкрите поле», що проводили до початку експерименту (вихідні дані) та через 2 тижні [8, с. 170].

В результаті проведених досліджень, можна констатувати помірну стреспротективну активність КГомЛЗ «Тонус-актив», що обумовлена 
антиоксидантними властивостями, а також ймовірним активізуючим впливом на гіпоталамо-гіпофізарно-наднирникову систему, що може виявлятись протективною дією. За допомогою інтегрального тесту «відкрите поле» виявлено, що «Тонус-актив» практично не впливає на стан ЦНС у інтактних щурів та не чинять на них седативний вплив.

\section{Література:}

1. Гайдукова О. О. Розробка та дослідження комплексного гомеопатичного препарату для лікування синдрому хронічної втоми. Автореф. дис. к. фарм. н., Харків, 2010. 23 с.

2. Ганеман С. Органон врачебного искусства. 1992. 208 с.

3. Мальцев Д. В. Синдром хронічної втоми, асоційований з герпесвірусними інфекціями. Міжнародний неврологічний журнал. 2019. № 4. С. 5-19

4. Райгородский Ю. М., Пономаренко Г. Н., Болотова Н. В., Череващенко Л. А. Транскраниальная физиотерапия при синдроме хронической усталости. Физиотерапия, бальнеология и реабилитация. 2015. № 14. С. 19-22

5. Стефанов О. В. Доклінічні дослідження лікарських засобів. 2001. 306 c.

6. Ткаченко А. В., Слинькова Т. А., Дьякова Д. А. Синдром хронической усталости и его связь с содержанием магния в организме. Здоровье и образование в ХХІ веке. 2018. № 12. С. 169-172

7. Яковлєва Л. В. Оцінка стреспротективної активності нових фармакологічних засобів адаптогенної дії на моделі гострого іммобілізаційного стресу. Вісник фармації. 2006. № 2. С. 60-63.

8. Gupta P., Sundaram E. N., Mahima S. at all. Pre-clinical pharmacology: an important aspect in homoeopathic research. Indian Journal of Research in Homoeopathy. 2018. № 12. P. 164-179.

9. Diane L. Solomon. Chronic fatigue syndrome: a guide to the homeopathic treatment of CFS/M.E. 2015. 220 p. 